\title{
The Hibiscus Erineum Mite, Aceria hibisci (Acari: Eriophyidae) a New Introduction in the Caribbean and a Potential Threat to Florida's Hibiscus ${ }^{1}$
}

\author{
Cal Welbourn, Jose Carlos Rodrigues and Jorge E. Peña ${ }^{2}$
}

The hibiscus erineum mite (=hibiscus erinose mite, hibiscus leaf-crumpling mite) was originally described as Eriophyes hibisci (Acari: Eriophyidae) from Hibiscus rosa-sinensis L. (Malvaceae) in the Fiji islands by Nalepa (1906) and later transferred to the genus Aceria (Keifer 1966). Feeding by this mite deforms young leaves and developing vegetative buds. Nalepa (1909) reported A. hibisci from the Samoan Islands with additional morphological and feeding damage details. The mite is also known from the Cook Islands and Tonga.

Hara et al. $(1996,2001)$ reported A. hibisci in Oahu, Hawaii, USA in 1989. Kumashiro (1998) reported A. hibisci on the Hawaiian island of Lanai in 1995. In 1992 the mite was reported from New South Wales, Australia where unconfirmed reports suggest it may have been established there as early as 1978 (Carson and Gough 2007). The mite is also widespread in southeastern Queensland (Carson and Gough 2007). Quilici et al. (1997) reported A. hibisci from Hibiscus sp. on Reunion Island. Aceria hibisci was first collected in the Caribbean region on the islands of Martinique in 1997 and Guadeloupe in 1998 and 2000 from Hibiscus rosa-sinensis and Hibiscus sp. (Flechtmann et al., 1999and Flechtmann and Etienne, 2001). De la Torre and Martinez reported the mite from Cuba in 2004 on Talipariti elatum (Sw.) Fryxell. (Malvaceae). Specimens from Dominica and Jamaica were submitted to the Division of Plant Industry, FDACS, in 2007 and early 2008 were confirmed as A. hibisci. Aceria hibisci has probably been in Jamaica since at least 2005 (J. Goldsmith, personnal communication). In Puerto Rico, galls have been observed in Hibiscus rosa-sinensis by personel of the local Department of Agriculture since 2000.

Aceria esculenti Keifer 1966 was described from okra, Abelmoschus esculentus Moench (=Hibiscus esculentus L.) based on specimens from Brazil. Jeppson et al (1975) and Perring (1996) without any explanation considered $A$. esculenti to be the same as A. hibisci. Perring (1996) also reported A. hibisci from "Easten Europe" without providing details on the host or locality. It remains to be established if $A$.

1. This document is ENY-852 (IN777), one of a series of the Entomology and Nematology Department, Florida Cooperative Extension Service, Institute of Food and Agricultural Sciences, University of Florida. First published: December 2008. Please visit the EDIS Web site at http://edis.ifas.ufl.edu.

2. Cal Welbourn, Florida Department of Agriculture and Consumer Services, Division of Plant Industry, Entomology, Gainesville, email: welbouc@ doacs.state.fl.us; Jose Carlos Rodrigues, University of Puerto Rico, Crop Protection Department, Jardín Botánico Sur, 1193 Calle Guayacan, San Juan PR, email: jose_carlos@mac.com;and Jorge E. Peña, Univeristy of Florida, Department of Entomology and Nematology, Tropical Research and Education Center, Homestead, FL, email: jepe@ifas.ufl.edu.

The Institute of Food and Agricultural Sciences (IFAS) is an Equal Opportunity Institution authorized to provide research, educational information and other services only to individuals and institutions that function with non-discrimination with respect to race, creed, color, religion, age, disability, sex, sexual orientation, marital status, national origin, political opinions or affiliations. U.S. Department of Agriculture, Cooperative Extension Service, University of Florida, IFAS, Florida A. \& M. University Cooperative Extension Program, and Boards of County Commissioners Cooperating. Larry Arrington, Dean 
esculenti and $A$. hibisci are the same or different species.

\section{Description}

All Eriophyoidea are obligate vascular plant feeders. Eriophyid mites can be distinguished from other phytophagous mites by their small size, wormlike body and two pairs of legs. Aceria hibisci are about $0.2 \mathrm{~mm}$ long and barely visable with a good handlens. The presence of this mite and many eriophyid mites can be established by the feeding damage (galls, erinea, bronsing, withches broom, etc) or by careful examination of plant material under a good dissecting microscope.

\section{Symptoms and Identification}

Feeding by the hibiscus erinium mite results in deformed leaves, stems, twigs and flowers. A common character is the production of puckered bumps on the leaves (leaf edge, leaf underside and leaf upperside) (Figures, 1-3). The underside of these bumps shows different compartments which are usually lined with a pale yellowish velvety growth called erinia. Leaf axils can also be deformed (Figure 2). Damage can also be observed on unopened flowers. Flowers affected by the mite show deformation and the galls are usually found on the internal part of the flowers (Figure 5). Damage on the lower part of the leaf stem is characterized by the production of a corky tissue. Other organisms (mites, plant bugs) can be found on these corky bumps, but their role in bump development is not determined yet. The gall development and leaf deformation is more intense when the infestation occurs on young leaves and developing vegetative buds.

Newly formed galls are as small as a pin head, greenish and pimple like, while galls that are well developed can measure around $0.2 \mathrm{~cm}$ in length and more increasing in size and length as mite feeding progresses.

\section{Dispersal}

Under natural conditions, the $A$. hibisci disperses probably on the wind along with most other plant feeding mites. Transport of infested plants or plant material is certainly a major mode of dispersal for

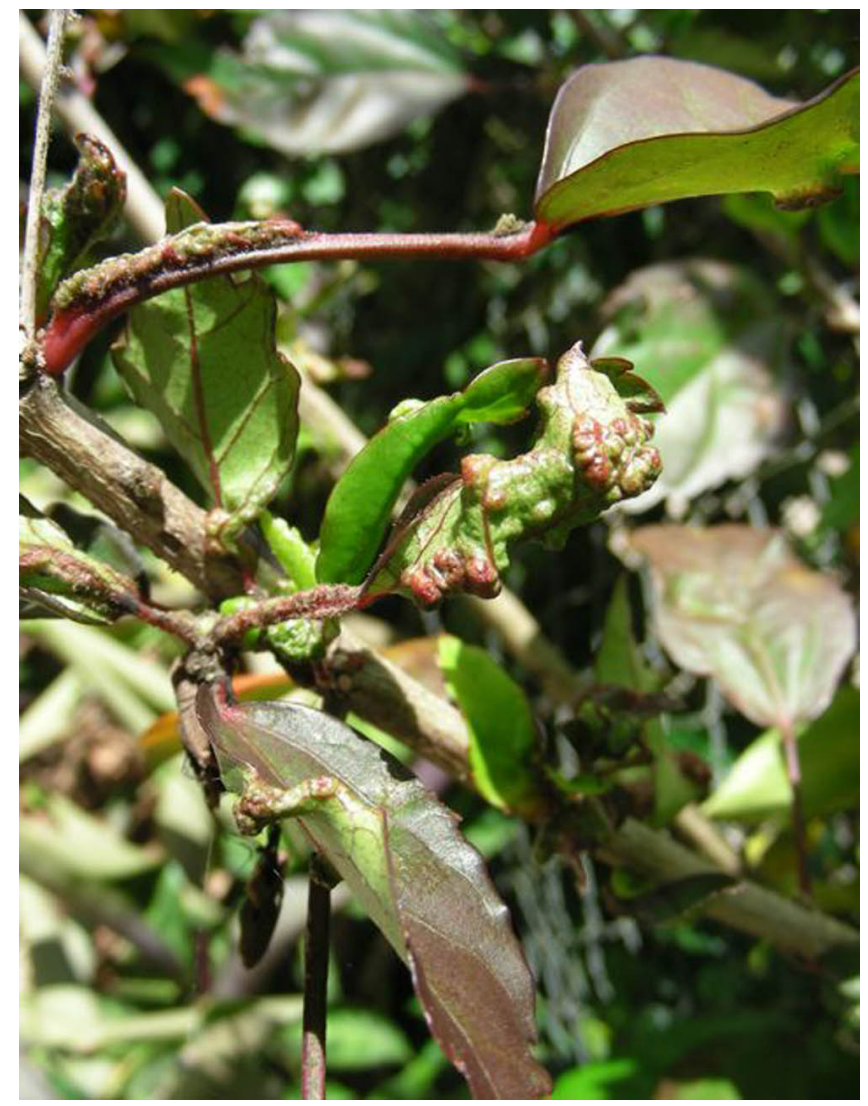

Figure 1. Galls formed on leaves and petioles of Hibiscus spp. Credits: J.C. Rodrigues

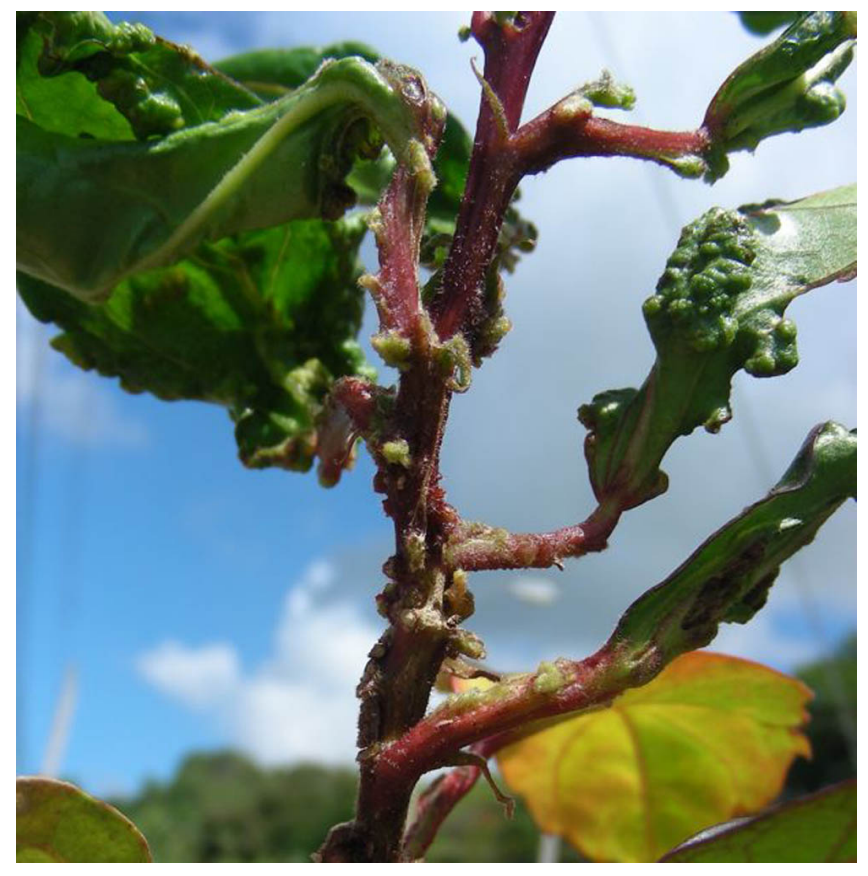

Figure 2. Galls formed on leaves and petioles of Hibiscus spp. Credits: J.C. Rodrigues

this mite because the hibiscus host plants are mostly propagated vegetatively. 


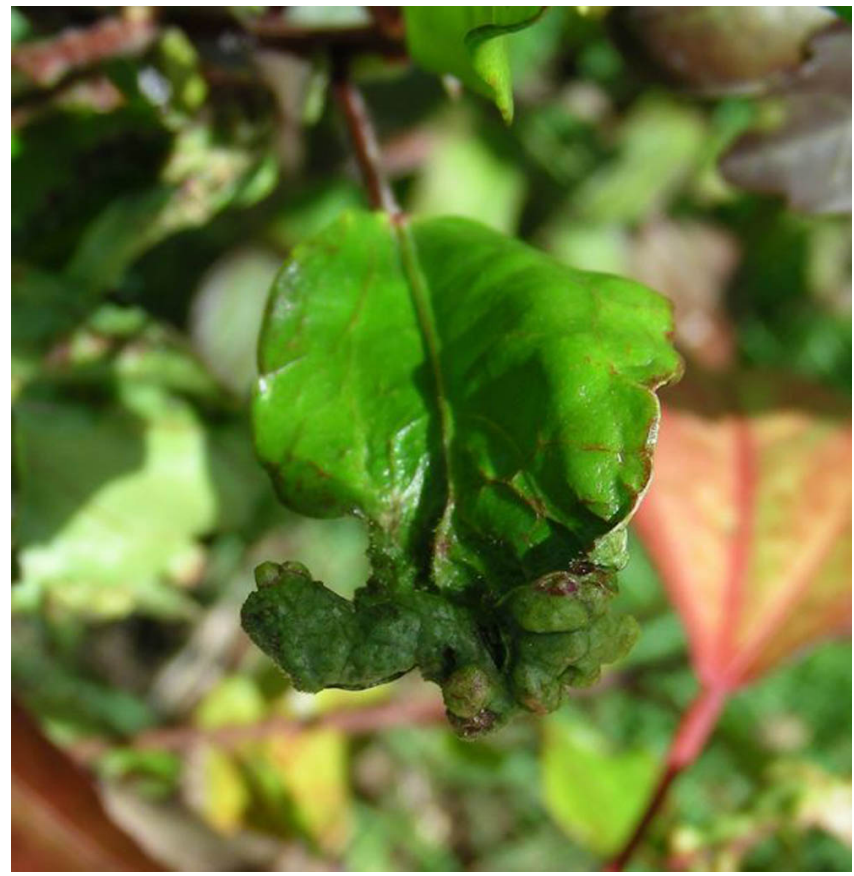

Figure 3. Galls formed on leaves and petioles of Hibiscus spp. Credits: J.C. Rodrigues

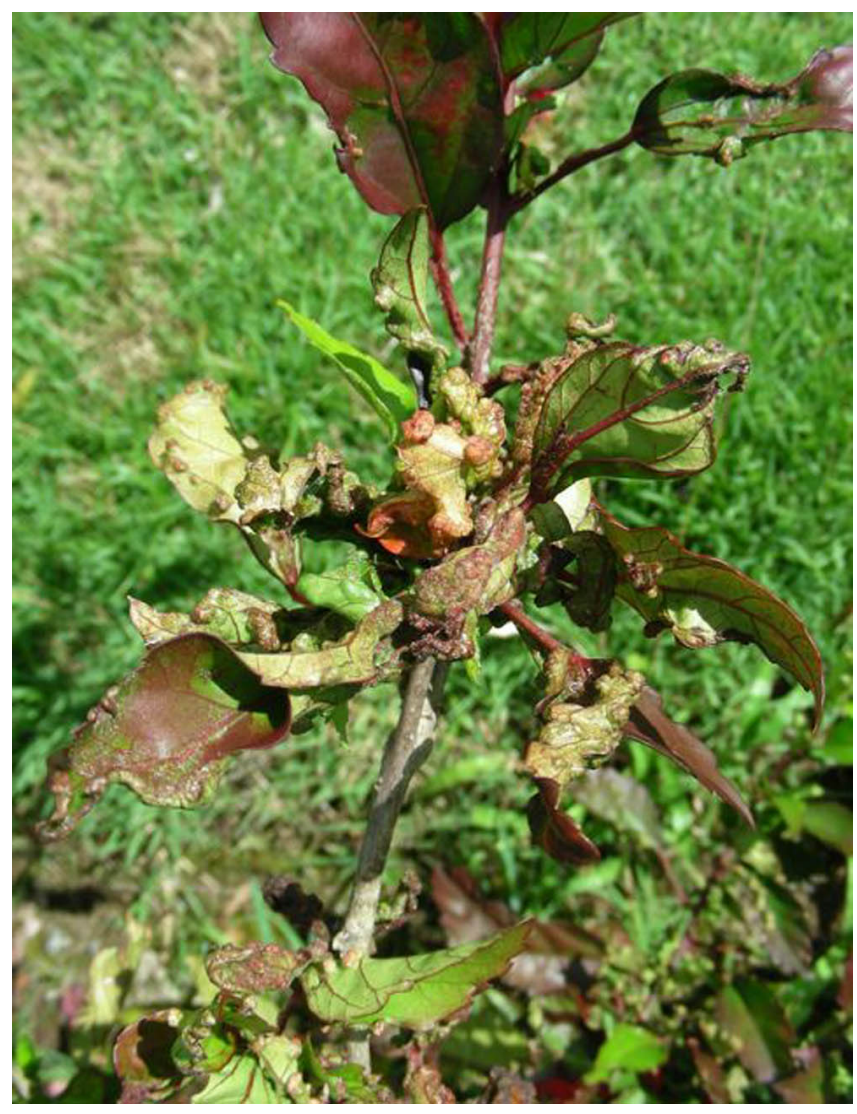

Figure 4. Hibiscus plant deformed by $A$. hibisci galls. Credits: J.C. Rodrigues

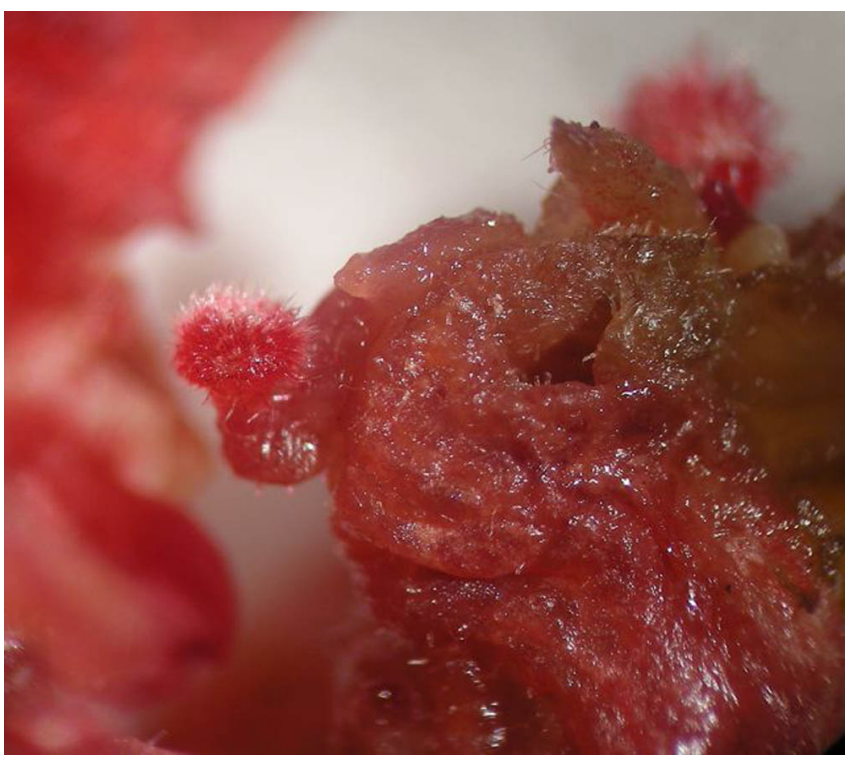

Figure 5. Galls on Hibiscus flowers. Credits: J.C. Rodrigues

\section{Hosts}

The hibiscus erineum mite appears to prefer Hibisicus rosa-sinensis (Chinese red hibiscus) througout most of its known range, but it will feed on other hibiscus species including Talipariti elatum (De la Torres and Martinez 2004). The host for A. hibisci from Reunion Island and some Caribbean sites were only identified as Hibiscus sp. Harra et al (2001) reported that the Hibisicus rosa-sinensis cultivars 'Apricot', 'Empire', 'Pink Hibiscus', 'Itsy Bitsy Peach “Monch"', '"Zham" Chinese', and 'Apple Blossom' were less susceptible to A. hibisci than 'Chinese Red', 'Herman Shierman', 'Orange hibiscus', 'Nii Yellow', and 'Kardinal' in tests conducted in Maui, Hawaii, USA. Aceria hibisci has been reported to attack Abelmoschus esculentus Moench (okra) causing irregular erineum pockets (Jeppson et al 1975, Perring 1996). In Puerto Rico, Malvaviscus arboreus Cav. (wax mallow) growing side by side with heavily infested hibiscus plants did not show galls or signs of infestation by the mite.

\section{Control}

Biological control. Predatory mites of the family Phytoseiidae have been found associated with the galls at several sites. Samples from Dominica, Jamaica and Puerto Rico had the predatory mites 219862149species219862149PEPena,Jorge E associated with the galls. On Reunion Island Phytoseius intermedius Evans and McFarlane was 
reported associated with A. hibisci on Hibiscus sp. At this time no other phytoseiid or predatory mite species associtated with the $A$. hibisci have been identified.

Cultural control. Pruning of infested branches is only a temporaty fix for an infestation. New growth on the same plant is frequently infested.

Chemical control. Specific chemical control recommendations are difficult due to label restrictions. For information on current acaricides registered for general outdoor ornaments or specifically for hibiscus, consult the local Cooperative Extension Service office. Chemical control will only affect the new growth and the already damagaed leaves will persist until they die or are pruned off. After any chemical treatment the affected plant parts should be pruned.

\section{References}

Carson, C. and N. Gough. 2007. Hibiscus erinos mite. (Accessed 2/15/2008) http://www.dpi.qld.gov.au/cps/rde/xchg/dpi/hs.xsl/ 26_8327_ENA_HTML.htm

Carson, C. and N. Gough. 2000. Hibiscus erineum mite. H00054. Queensland Horticulture Indstitute, Deptartment of Primary industries, Queensland, Australia.

De la Torre, P.E. and H. Martinez. 2004. Lista de los acaros eriofioides (Acari: Prostigmata: Eriophyoidea) de cuba. Revists Iberica de Aracnologia 9: 123-126.

Flechtmann, C.H.W., S. Kreiter, J. Etienne and G.J. De Moraes. 1999. Plant mites (Acari) of the French Antilles. 4. Eriophyidae (Prostigmata). Acarologia 40(3): 321-342.

Flechtmann, C.H.W. and J. Etienne. 2001. Plant mites from Guadeloupe and French Guyana with descriptions of five new species of eriophyid mites (Acari: Eriophyidae, Tenuipalpuidae, and Tetranychidae). International Journal of Acarology 27(4): 261-270.

Hara, A., D. Tsuda, J. Tavares, J. Yogi, and D. Hensley. 1996. Hibiscus erineu mite. Univerity of
Hawaii at Manoa, Cooperative Extension Service, Inesct Pests, Instant Information Series No. 18.

Hara, A., D. Tsuda, J. Tavares, J. Yogi, and D. Hensley. 2001. Hibiscus erineu mite. Univerity of Hawaii at Manoa, Cooperative Extension Service, Inesct Pests, IP-7.

Jeppson, L.R., H.H. Keifer, and E.W. Baker. 1975. Mites injurious to economic plants. University of Califoria Press. Berkeley. 679 pp.

Keifer, H.H. 1966. Eriophyid studies B-20. Bureau of Entomology, California Department of Agriculture, 20 pp.

Kumashiro, B. 1998. New Hawaii state, island and host records. IN Proceedings of the Hawaiian Entomological Sociery for the years 1994, 1995. Proceedings of the Hawaiian Entomological Society $33: 1-8$.

Nalepa, A. 1906. Ueber zwei neve Eriophyiden von den Fidschiinseln. Journal of Economic Biol. 1(4): 147-151.

Nalepa, A. 1909. Eriophyiden. In K. Rehniner, Botanische und zoologische Ergebnisse einer wissenschaftlichen Forschungsreise nach den Samooninseln, dem Neuguinea-Archipel und den Salomoainseln, dem Neuguinea-Archipel und den Salomoninseln, von Maerz dis Dez. 1905. Denks. Kais. Akad. Wissensch. Wien, 84: 523-536.

Perring, T.M. 1996. 3.2.7 Vegetables. Pp 593-610. IN. E.E. Lindquist, M.W. Sabelis \& J. Bruin (Eds). World Crop Pets 6. Eriophyid mites - Their biology, natural enemies and control. Elsevier, Amsterdam. 790 pp.

Quilici, S. S. Krieter, E.A. Ueckekrmann and D. Vancenot. 1997. Predatory mites (Acari) from various crops on Reunion Island. International Journal of Acarology 23(4): 283-291. http://www.ento.csiro.au/aicn/name_s/b_28.htm

http://www.ento.csiro.au/aicn/system/c_55.htm

http://cookislands.bishopmuseum.org/ species.asp?id=14666 
The Hibiscus Erineum Mite, Aceria hibisci (Acari: Eriophyidae) a New Introduction in the....

http://www.green-seeds.com/PDF/

hibiscus_er_mite.pdf

"http://www.ctahr.hawaii.edu/nelsons/Misc/

http://www.ento.csiro.au/aicn/name_c/

a_2031.htm 